\title{
Diagnosa Penyakit Hepatitis Menggunakan Metode Weighted Product
}

\author{
1)Parlindungan Sihaloho
}

UNIKA Santo Thomas SU, JI. Setiabudi No. 479 F, Sumatera Utara, Indonesia http://www.ust.ac.id, Email : sihalohoparlindungan@gmail.com

\section{${ }^{2)}$ Wasit Ginting}

UNIKA Santo Thomas SU, JI. Setiabudi No. 479 F, Sumatera Utara, Indonesia http://www.ust.ac.id,Email : mmcbyes@gmail.com

\begin{abstract}
Hepatitis is an inflammatory process in the liver tissue. Hepatitis in lay language is often referred to as liver or jaundice. Viral hepatitis infection can develop into cirrhosis or hardening of the liver even liver cancer, inflammation / inflammation and injury to the liver due to hepatic reactions to various conditions, especially viruses, drugs and alcohol. Hepatitis Diagnosis Expert System has been developed with a weighted product method. The weight product method diverts the results of the assessment of each attribute. The results of these multiplications have not been meaningful if they have not been compared with standard values. The weight for the benefit attribute functions as a positive power in the multiplication process, while the cost weight functions as a negative power multiplying the attribute value of each symptom that has been weighted for.From the results of the trials that have been carried out the system has been able to diagnose hepatitis A, B, C, D, E based on the symptoms entered by the patient.
\end{abstract}

Keywords: Expert System, Weighted Product, Hepatic Disease

\section{PENDAHULUAN}

Penyakit hepatitis adalah suatu penyakit yang merusak organ hati manusia, hati merupakan organ yang sangat penting bagi tubuh manusia . Hati sebagai organ yang memiliki tugas utama sebagai penetral racun-racun yang selama ini masuk kedalam tubuh manusia dari makanan ataupun lingkungan yang mampu dinetralisir oleh hati. Hepatitis merupakan penyakit peradangan hati karena berbagai sebab. Penyebab tersebut adalah beberapa jenis virus yang menyerang dan menyebabkan peradangan dan kerusakan pada sel-sel dan fungsi organ hati.

Sistem pakar merupakan program komputer untuk dapat meniru proses kemahiran dan pengetahuan pakar untuk menyelesaikan suatu masalah yang spesifik. Pengetahuan dari pakar digunakan sebagi dasar oleh sistem pakar untuk menjawab pertanyaan (konsultasi). Bentuk umum sistem pakar adalah suatu program yang dibuat berdasarkan suatu set aturan yang menganalisis informasi (biasanya diberikan oleh pengguna suatu sistem) mengenai suatu kelas masalah spesifik serta analisis matematis dari masalah tersebut. Tergantung dari desainnya, sistem pakar juga mampu merekomendasikan suatu rangkaian tindakan pengguna untuk dapat menerapkan koreksi.

Metode weighted product digunakan untuk melakukan proses normalissi pada setiap nilai atribut. Pada metode ini mencari alternatif yang terbaik dari banyak alternatif yang ada dengan cara memberikan bobot setiap kriteria untuk alternatif tersebut dan metode weighted product ini lebih efisien karena waktu yang dibutuhkan dalam perhitungan lebih singkat.

\section{KAJIAN TEORI}

\section{Sistem Pakar}

Sistem pakar adalah sistem komputer yang ditujukan untuk meniru semua aspek(emulates) kemampuan pengambilan keputusan (desicion making) seorang pakar. Sistem pakar memanfaatkan secara maksimal pengetahuan khusus selayaknya seorang pakar untuk memecahkan masalah. (Rosnelly,2012)

\section{Struktur Sistem Pakar}




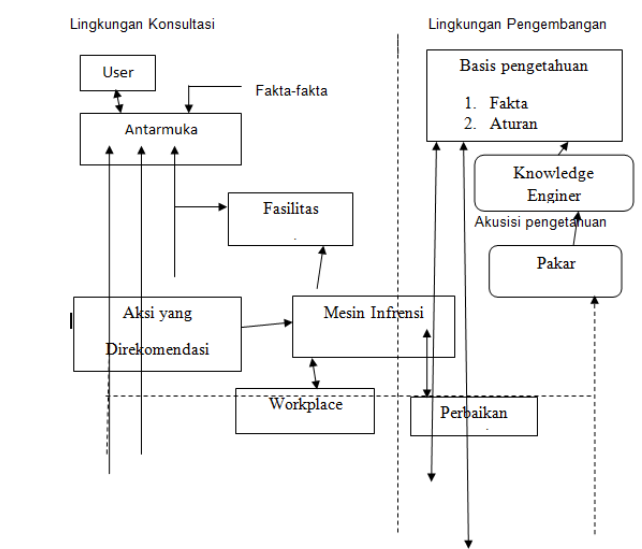

Gambar 1. Arsitektur Sistem Pakar (Arhami , 2012)

\section{Metode Weighted Product}

Metode Weighted Product memerlukan proses normalisasi karena metode ini mengalihkan hasil penilaian setiap atribut. Hasil perkalian tersebut belum bermakna jika belum dibandingkan (dibagi) dengan nilai standart. Bobot untuk atribut manfaat berfungsi sebagai pangkat positif dalam proses perkalian, sementara bobot biaya berfungsi sebagai pangkat negative ${ }^{[1]}$.

Metode Weighted Product menggunakan perkalian sebagai untung menghubungkan rating atribut, dimana rating setiap atribut harus dipangkatkan dulu dengan bobot yang bersangkutan. Proses ini sama halnya dengan proses normalisasi. Preferensi untuk alternatif Si diberikan sebagai berikut :

Preferensi untuk alternatif diberikan sebagai berikut :

$S_{i}=\prod_{j=1}^{n}\left(X_{i j}\right) w j$

Keterangan :

$S=$ Preferensi alternatif dianalogikan sebagai vektor $\mathrm{S}$

$X i j=$ Nilai variabel dari alternatif pada setiap atribut

$w j=$ Nilai bobot kriteria

$\mathrm{n}=$ Banyaknya kriteria

$\mathrm{i}=$ Nilai alternatif

$\mathrm{j}=$ Nilai kriteria

dimana $\Sigma \mathrm{Wj}=1 . \mathrm{Wj}$ adalah pangkat bernilai positif untuk atribut keuntungan, dan bernilai negatif untuk atribut biaya.

Preferensi relatif dari setiap alternatif, diberikan sebagai :
$V_{i=} \frac{\prod_{j=1}^{n}\left(X_{i j}\right)^{w j}}{\prod_{j=1}^{n}\left(W_{j}^{*}\right)^{w j}}$

Keterangan :

$\mathrm{V}=$ Preferensi relative dari setiap alternatif dianalogikan vektor $\mathrm{V}$

$\mathrm{Xij}=$ Nilai variabel dari alternatif pada setiap atribut

wj = Nilai bobot kriteria

$\mathrm{n}=$ Banyaknya kriteria

$\mathrm{i}=$ Nilai alternatif

$\mathrm{j}=$ Nilai kriteria

* = Banyaknya kriteria yang telah dinilai pada vektor S

\section{PERANCANGAN}

1.Perancangan Basis Pengetahun.

Dari hasil pencatatan di lapangan diperoleh data gejala-gejala penyakit hepatisi seperti terlihat di Tabel 1.

Tabel 1. Sumber Pengetahuan Gejala Penyakit Hepatitis

\begin{tabular}{|l|l|l|}
\hline No & $\begin{array}{l}\text { Kode } \\
\text { Gejala }\end{array}$ & Gejala penyakit \\
\hline 1 & G01 & Mengalami demam \\
\hline 2 & G02 & $\begin{array}{l}\text { Tubuh cepat merasa lemah } \\
\text {,letih,lesu dan mudah lelah }\end{array}$ \\
\hline 3 & G03 & Kehilangan nafsu makan \\
\hline 4 & G04 & Rasa mual dan muntah \\
\hline 5 & G05 & Nyeri dan otot \\
\hline 6 & G06 & Mata kuning \\
\hline 7 & G07 & Tinja berwarna abu-abu \\
\hline 8 & G08 & $\begin{array}{l}\text { Bengkak pada perut bangian } \\
\text { atas }\end{array}$ \\
\hline 9 & G09 & Gatal-gatal pada kulit \\
\hline 10 & G10 & Urin berwarna gelap \\
\hline
\end{tabular}

Setelah mengetahui gejala penyakit yang diderita pasien maka perlu diketahui penyakit yang diderita pasien tersebut termasuk didalam tipe jenis penyakit hepatitis pada Tabel 2. dibawah ini.

Tabel 2. Sumber Pengetahuan Jenis Penyakit Hepatitis

\begin{tabular}{|l|l|l|}
\hline No & $\begin{array}{l}\text { Kode } \\
\text { Penyakit }\end{array}$ & Nama Penyakit \\
\hline 1 & P01 & Hepatitis A \\
\hline 2 & P02 & Hepatitis B \\
\hline 3 & P03 & Hepatitis C \\
\hline 4 & P04 & Hepatitis D \\
\hline 5 & P05 & Hepatitis E \\
\hline
\end{tabular}

Tabel 3. Nilai Alternative Setiap Kriteria

\begin{tabular}{|l|l|l|l|l|l|l|l|l|l|l|}
\hline Alternative & \multicolumn{1}{|c|}{ Kriteria } \\
\cline { 2 - 8 } & G1 & G2 & G3 & G4 & G5 & G6 & G7 & G8 & G9 & G10 \\
\hline
\end{tabular}


ISSN : 2548-6985

\begin{tabular}{|l|l|l|l|l|l|l|l|l|l|l|}
\hline Hepatitis A & 5 & 1 & 1 & 1 & 1 & 5 & 5 & 1 & 1 & 1 \\
\hline Hepatitis B & 1 & 5 & 5 & 1 & 5 & 1 & 1 & 5 & 5 & 1 \\
\hline Hepatitis C & 1 & 5 & 3 & 5 & 1 & 5 & 1 & 5 & 1 & 5 \\
\hline Hepatitis D & 1 & 5 & 1 & 1 & 1 & 1 & 5 & 1 & 1 & 5 \\
\hline Hepatitis E & 5 & 5 & 5 & 5 & 5 & 5 & 5 & 5 & 5 & 1 \\
\hline Pasien & 5 & 1 & 1 & 5 & 5 & 1 & 5 & 1 & 1 & 1 \\
\hline
\end{tabular}

Tabel 4. Penentuan Nilai W

\begin{tabular}{|c|c|c|}
\hline Gejala & Range(\%) & Bobot \\
\hline G1 & 20 & 0,2 \\
\hline G2 & 5 & 0,05 \\
\hline G3 & 5 & 0,05 \\
\hline G4 & 5 & 0,05 \\
\hline
\end{tabular}

\begin{tabular}{|c|c|c|}
\hline G5 & 5 & 0,05 \\
\hline G6 & 20 & 0,2 \\
\hline G7 & 10 & 0,1 \\
\hline G8 & 5 & 0,05 \\
\hline G9 & 20 & 0,2 \\
\hline G10 & 5 & 0,05 \\
\hline
\end{tabular}

Kemudian Vektor $\mathrm{S}$ dihitung dengan berdasarkan persamaan:

$S_{i}=\prod_{J}^{n}=1 x_{i j} w_{j}$, dengan $1,2, \ldots \mathrm{m}$ dimana $\Sigma \mathrm{Wj}=1 . \mathrm{Wj}$, Kemudian vektor $\mathrm{S}$ dapat dihitung sebagai berikut

$\left.S 1=\left(5^{0,2}\right)\left(1^{0,05}\right)\left(1^{0,05}\right)\left(1^{0,05}\right)\left(1^{0,05}\right)\right)\left(5^{0,2}\right)\left(5^{0,1}\right)\left(1^{0,05}\right)\left(1^{0,2}\right)\left(1^{0,05}\right)=2,236067977$

Dan perhitungan Vektor $S$ yang lain seperti dibawah ini:

$\left.\mathrm{S} 1=\left(5^{0,2}\right)\left(1^{0,05}\right)\left(1^{0,05}\right)\left(1^{0,05}\right)\left(1^{0,05}\right)\right)\left(5^{0,2}\right)\left(5^{0,1}\right)\left(1^{0,05}\right)\left(1^{0,2}\right)\left(1^{0,05}\right)=2,236067977$

$\left.\mathrm{S} 2=\left(1^{0,2}\right)\left(5^{0,05}\right)\left(5^{0,05}\right)\left(1^{0,05}\right)\left(5^{0,05}\right)\right)\left(1^{0,2}\right)\left(1^{0,1}\right)\left(5^{0,05}\right)\left(5^{0,2}\right)\left(1^{0,05}\right)=1,903653939$

S3 $\left.=\left(1^{0,2}\right)\left(5^{0,05}\right)\left(3^{0,05}\right)\left(5^{0,05}\right)\left(1^{0,05}\right)\right)\left(5^{0,2}\right)\left(1^{0,1}\right)\left(5^{0,05}\right)\left(1^{0,2}\right)\left(5^{0,05}\right)=2,011148153$

S4 $\left.=\left(1^{0,2}\right)\left(5^{0,05}\right)\left(1^{0,05}\right)\left(1^{0,05}\right)\left(1^{0,05}\right)\right)\left(1^{0,2}\right)\left(5^{0,1}\right)\left(1^{0,05}\right)\left(1^{0,2}\right)\left(5^{0,05}\right)=1,756465005$

S5 $\left.=\left(5^{0,2}\right)\left(5^{0,05}\right)\left(5^{0,05}\right)\left(5^{0,05}\right)\left(5^{0,05}\right)\right)\left(5^{0,2}\right)\left(5^{0,1}\right)\left(5^{0,05}\right)\left(5^{0,2}\right)\left(1^{0,05}\right)=4,613404173$

S_User $\left.=\left(5^{0,2}\right)\left(1^{0,05}\right)\left(1^{0,05}\right)\left(5^{0,05}\right)\left(5^{0,05}\right)\right)\left(1^{0,2}\right)\left(5^{0,1}\right)\left(1^{0,05}\right)\left(1^{0,2}\right)\left(1^{0,05}\right)=1,903653939$

Nilai vektor $\mathrm{V}$ yang digunakan untuk perangkingan dapat dihitung berdasarkan:

$V_{i}=\frac{\Pi_{J}^{n}=1 x_{i j} w_{j}}{\prod_{J}^{n}\left(x_{j} * w_{j}\right.}$

$\mathrm{V} 1=\frac{2,236067977}{2,236067977+1903653939+2,011148153+1756468}$

2,236067977

$=0,155019899$

$\mathrm{V} 2=\frac{1,903653939}{2,236067977+1,903653939+2,011148153+1,756465005+4,613404173+1,903653939}$ $=0,131974629$

$\mathrm{V} 3=$

2,011148153

$2,236067977+1,903653939+2,011148153+1,756465005+4,613404173+1,903653939$ $=0,139426881$

$\mathrm{V} 4=\frac{1,756465005}{2,236067977+1,903653939+2,011148153+1,756465005+4,613404173+1,903653939}$ $=0,121770461$

V5 $=\frac{4,613404173}{2936067977+1,903653939+2,011148}$

4,613404173

$=0,319833501$

Pasien $=\frac{1,903653939}{2,236067977+1,903653939+2,0114893+1,756465}$

1,903653939

$=0,131974629$

Berdasarkan perhitungan di atas maka dapat disimpulkan pasien menderita penyakit hepatitis $B$ karena nilai perhitungan hasil dari pasien menunjukkan ke hepatitis $B$

\section{Rancangan Proses}

Diagram konteks adalah alur data yang berfungsi untuk menggambarkan keterkaitan aliran-aliran data antara sistem dengan bagian-bagian luar. Sistm Pakar Mendiagnosa Penyakit Hepatitis berinterkasi dengan pasien dan admin seperti yang diperlihatkan pada Gambar 2. Admin memasukkan data gejala, 
penyakit dan besaran bobot gejala. Sebelum melakukan diagnosa maka pasien terlebih dahulu melakukan pendaftaran selanjutnya melakukan diagnosa dengan menjawab pertanyaan yang diberikan sistem. Setelah pasien menjawab semua pertanyaan maka sistem akan menampilkan hasil diagnosa penyakit.

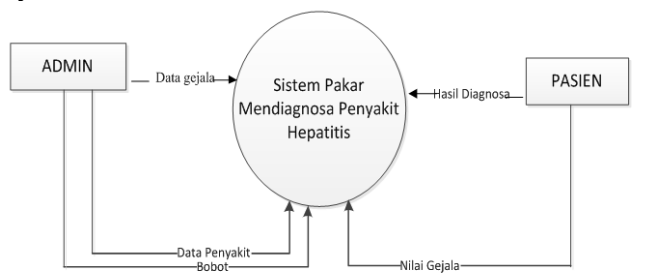

Gambar 2. Diagram Konteks

\section{Rancangan Antar Muka}

Antar muka pemakai dirancang untuk memudahkan pengguna (user) berinteraksi dengan sistem. Terdapat dua jenis antar muka yang dirancang yaitu rancangan untuk Admin dan rancangan untuk Pasien.

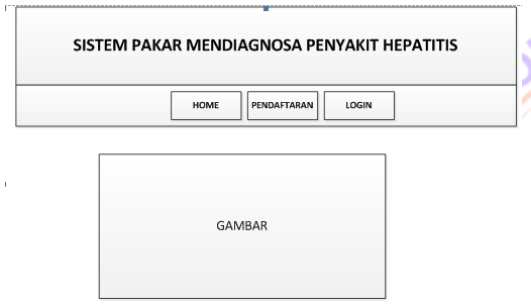

\section{Gambar 3. Form Halaman Utama}

\section{HASIL DAN PEMBAHASAN}

\section{Form Menu Utama}

Menu utama yang terdiri dari home,konsultasi dan login. Untuk masuk kesub berikutnya maka harus dipilih salah satu menu yang ada pada menu utama seperti terlihat pada Gambar 11.

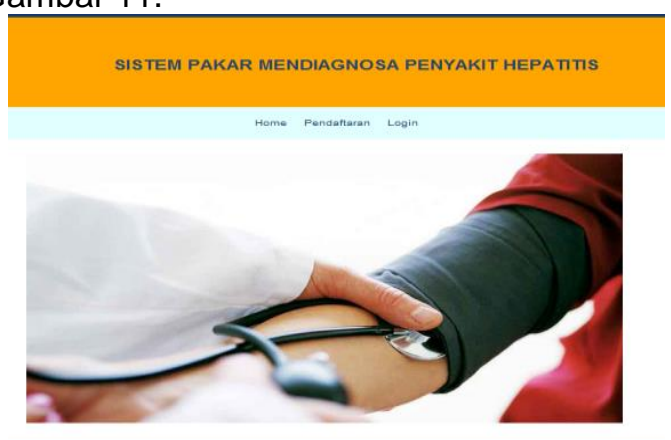

Gambar 4. Tampilan Form Menu Utama

\section{Tampilan Form Pendaftaran}

Pada form ini pasien mengisi data diri seperti nama, umur, jenis kelamin, no hp dan alamat seperti yang ditujukkan Gambar 13.

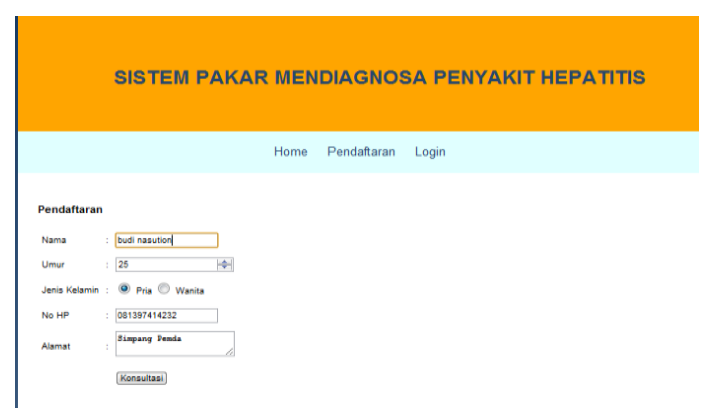

Gambar 5. Tampilan Form Pendaftaran

\section{Tampilan Form Konsultasi}

Konsultasi dapat dilakukan dengan cara memilih gejala-gejala yang ditampilakan pada form seperti terlihat pada Gambar 14. Proses ini akan dilakukan berulang dan berakhir setelah pengguna menjawab semua pernyataan.

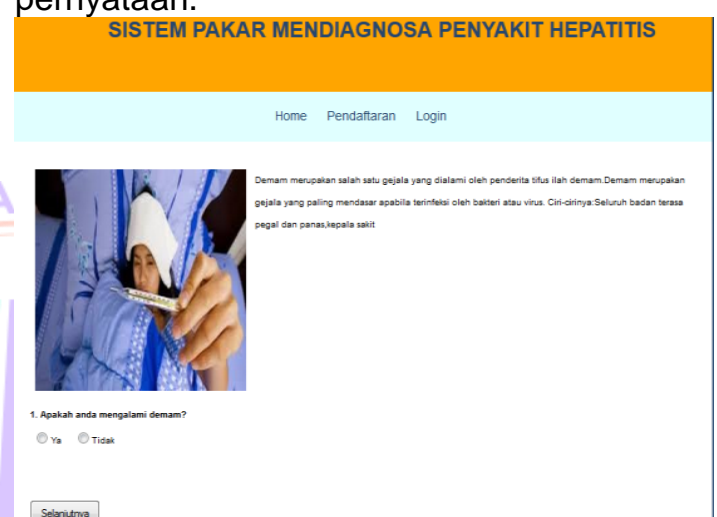

\section{Gambar 6. Tampilan Form Konsultasi}

Setelah pengguna menjawab seluruh pertanyaan maka sistem akan menampilkan hasil seperti Gambar 15. Terlihat pengguna yang menggunakan sistem, gejala-gejala penyakit pasien, hasil pengolahan sistem, dan dari gejala tersebut sistem mengambil kesimpulan pasien didiagnosa terkena penyakit Hepatitis B.

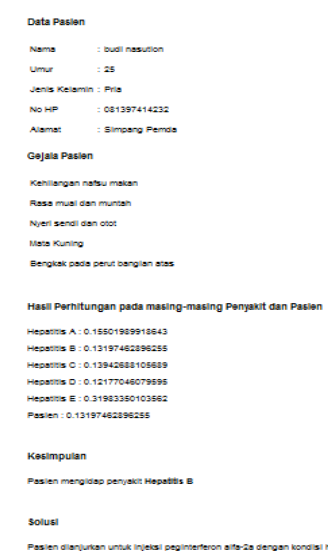

Gambar 7. Tampilan Hasil Konsultasi Pasien 


\section{PENUTUP}

Berdasarkan hasil yang diperoleh maka dapat diambil kesimpulan:

1. sistem pakar untuk mendiagnosa penyakit hepatitis ini membantu pengguna tentang pengetahuan penyakit hepatitis

2. sistem pakar dapat mempermudah tugas dokter dalam memberikan hasil penyakit yang di derita pasien

3. Sistem pakar yang dikembangkan dapat melakukan penelusuran lebih cepat sehingga dapat meningkatkan efisiensi dan efektifitas kerja.

4. Inferensi dengan menggunakan metode weighted product memudahan pengurutan penyakit hepatitis berdasarkan gejala-gejala yang dialami pasien berdasarkan tingkat kepentingan pada setiap kriteria. Dan sistem dapat membantu pasien menegetahui jenis penyakit hepatitis yang diderita dan diiberikan solusi pengobatnnya

\section{DAFTAR PUSTAKA}

1. Arhami, Muhammad. 2012. Konsep Dasar Sistem Pakar. Yogyakarta.Penerbit Andi

2. Adelia dan Jimmy Setiawan, Implementasi Costumer Relationship Management (CRM) pada Sistem Reservasi Hotel Berbasisi Website dan Dekstop, Jurnal Sistem Informasi, Vol 6, No.2, 2011.

3. Jogianto, HM, 2013, Analisa dan Desain Sistem Informasi, Andi Offset Yogyakarta

4. Rosnelly,Rika,2011, Sistem Pakar, Medan, Andi Offste Yogyakarta

5. Siswojo,B.Dkk.Diagnosis Penyakit Hati Melalui Sistem Pakar.Jurnal Computech Dan Bisnis.Vol.2.No 1.ISNN:1987-9629

6. Tata,Sutabri ,2012,Analisis Sistem Informasi.Yogyakarta .Penerbit Andi

7. Turban, Efraim, 2012, Decision Support System, Addision Wesley

8. Universitas Dian Nuswantoru.Implementasi Metode Weighted Product (WP) Dalam Sistem Pendukung Keputusan Untuk Menyelesaikan Penerima Masyarakat Miskin (Raskin).Techo.Com. Vol .14, No.2.ISNN:109-114

9. Nur Arifah Syafitri.2016.Penerapan Metode Weighted Product Dalam Sistem Pendukung Keputusan Pemilihan Laptop Berbasis Web.Semantik.Vol.2.No.1. ISSN: 2502-892 